\title{
Correction to: A smartphone application to objectively monitor music listening habits in adolescents
}

Danique E. Paping ${ }^{1,2^{*}}$, Jantien L. Vroegop ${ }^{1}$, Simone P. C. Koenraads ${ }^{1,2}$, Carlijn M. P. le Clercq ${ }^{1,2}$, André Goedegebure ${ }^{1}$, Robert J. Baatenburg de Jong ${ }^{1}$ and Marc P. van der Schroeff ${ }^{1}$

\section{Correction to: J Otolaryngol Head Neck Surg 50, 11 (2021)} https://doi.org/10.1186/s40463-020-00488-5

Following publication of the original article [1], the authors identified an error (omitted text) in Fig. 1. The correct figure is given below and the original article has been corrected.

Published online: 12 August 2021

\section{Reference}

1. Paping, et al. A smartphone application to objectively monitor music

listening habits in adolescents. J Otolaryngol Head Neck Surg. 2021;50:11.

https://doi.org/10.1186/s40463-020-00488-5.

\footnotetext{
The original article can be found online at https://doi.org/10.1186/s40463020-00488-5.

* Correspondence: d.paping@erasmusmc.nl

'Department of Otorhinolaryngology, Head and Neck Surgery, Erasmus

University Medical Center, Rotterdam, The Netherlands

${ }^{2}$ The Generation R Study Group, Erasmus University Medical Center,

Rotterdam, The Netherlands
}

(c) The Author(s). 2021 Open Access This article is licensed under a Creative Commons Attribution 4.0 International License, which permits use, sharing, adaptation, distribution and reproduction in any medium or format, as long as you give appropriate credit to the original author(s) and the source, provide a link to the Creative Commons licence, and indicate if changes were made. The images or other third party material in this article are included in the article's Creative Commons licence, unless indicated otherwise in a credit line to the material. If material is not included in the article's Creative Commons licence and your intended use is not permitted by statutory regulation or exceeds the permitted use, you will need to obtain permission directly from the copyright holder. To view a copy of this licence, visit http://creativecommons.org/licenses/by/4.0/ The Creative Commons Public Domain Dedication waiver (http://creativecommons.org/publicdomain/zero/1.0/) applies to the data made available in this article, unless otherwise stated in a credit line to the data. 
2,928 Visited the research center between May 2017 and March 2019

1,965 No consent or no (Android) smartphone

24 Technical issues smartphone application

18 Not invited to participate

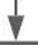

160 Unknown

761 With an Android Smartphone interested in participating

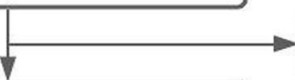

390 Smartphone application not installed

371 Installed the smartphone application

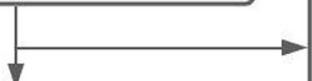

56 Time of installation $<7$ days

2 Time of installation or time between first and

last measurement $>40$ days

2 Listening levels incorrectly converted

311 Listening habits monitored over a period of 7 to 40 days (Part I)

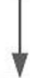

237 Completed the postal questionnaire on listening habits (Part II)

Fig. 1 Flow chart of study sample 